\title{
THE CONTRIBUTION OF BUGIS' TRADITIONAL GAMES IN STRENGTHENING STUDENTS' CHARACTER EDUCATION AT MADRASA
}

\author{
Sarifa Suhra \\ IAIN Bone \\ Bone, Sulawesi Selatan, Indonesia 92713 \\ Email: sarifasuhra@gmail.com

\section{Dedi Djubaedi} \\ IAIN Syeikh Nurjati Cirebon \\ Jl. Perjuangan, Sunyaragi, Cirebon, Indonesia, 45132 \\ Email:dedidjubaedi@syekhnurjati.ac.id
}

\section{Awg Asbol bin Haji Mail}

Akademi Pengajian Brunei, Universiti Brunei

Jalan Tungku Link, Gadong Brunei Darussalam, BE1410

Email: asbol.mail@ubd.edu.bn

Received: 09, 2020. Accepted: 12, 2020. Published: 12, 2020

\begin{abstract}
Bugis' traditional game originated from a folklore which is usually played by the society including children in Bone. It examines specifically mappasajang traditional game, its character value promotion and its contribution in strengthening students' character education at madrasa. This study was qualitative and took place at Madrasah Ibtidaiyah Amir al-Jannah Tippulue, Bone Regency. Primary data of this study were obtained from field observations and interviews with educational and community leaders. Secondary data were obtained from books and journals related to Bugis traditional games. Observation, interviews, and documentation were applied to gain the data. Qualitative data analysis was performed using interactive model analysis techniques. Triangulation was applied to test the validity of the data. The results showed that mappasajang traditional game could be played by both male and female madrasa students. This traditional Bugis game is full of character values. The traditional game contributed to strengthening students' character education at madrasa. This can be seen in various aspects of community life, such as in the fields of education, social, economy, and health.
\end{abstract}

Keywords: Character Education, Character Values, Mappasajang, Traditional Games

\section{ABSTRAK}

Permainan tradisional Bugis awalnya sebuah biburan rakyat yang sering dimainkan di kalangan masyarakat umum termasuk peserta didik di wilayah Bone. Tulisan ini mengkaji permainan tradisonal Bugis di Kabupaten Bone yang dibatasi pada permainan mappasajang dilihat dari nilai-nilai karakter dan kontribusinya bagi penguatan pendidikan karakter. Jenis penelitian ini kualitatif yang berlokasi di Madrasah Ibtidaiyah Amir al-Jannah Tippulue Kabupaten Bone. Data penelitian primer penelitian ini diperoleh dari observasi lapangan dan wawancara dengan tokoh pendidikan dan tokoh masyarakat. Data sekunder diperoleh dari buku dan jurnal terkait dengan permainan tradisional Bugis. Teknik, pengumpulan data yang digunakan observasi, wawancara, dan dukumentasi. Analisis data secara kualitatif dilakukan dengan menggunakan teknik analisis model interaktif. Pengujian keabsahan data dalam penelitian ini menggunakan teknik triangulasi. Triangulasi digunakan untuk mengecek keabsaban data dari sumber, metode, dan waktu. Hasil penelitian menunjukkan bahwa permainan tradisional Bugis mappasajang dapat dilakukan oleh peserta didik laki-laki dan perempuan. Permainan tradisional Bugis tersebut sarat dengan nilai-nilai karakter. Permainan taradisonal Bugis mappasajang berkontribusi bagi penguatan pendidikan karakter. Hal itu tampak dalam berbagai aspek, kehidupan masyarakat, seperti dalam bidang pendidikan, sosial, ekonomi, dan kesehatan.

Kata Kunci: Nilai-nilai Karakter, Mappasajang, Pendidikan Karakter, Permainan Tradisional 


\section{INTRODUCTION}

In Indonesia, national development programs require quality human resources to ensure that the implementation of the program can be properly conducted. Quality human resources requires good quality of education. At the heart of education is character education which is needed in order to prepare reliable human resources to build the nation's dignity (Azra, 2002; Suhra, 2016). Character education is geared toward instilling character values to internalize and perform by students. It emphasizes knowledge, individual awareness, determination, willingness and action to carry out values when it comes to maintain relationship with God, self and society. This serves as an effort to achieve the so-called insan kamil or human with noble character (Aunillah, 2011).

Character education is taken from two words. The term Character in English means trait. In Greek language, it means to mark and in its broadest sense is to focus on how to apply the values of goodness in real action. This definition confirms that character is the totality of personal characteristics which is inherent and identifiable in individual behavior that is unique. (Audi, 1999; Direktorat Jenderal Pendidikan Islam, 2016; Mulyasa, 2011) In line with this, Indonesian government puts strong emphasis on the effort to achieve the noble character for its citizen. To achieve this, the government has set the goals of national education that is to provide a proper foundation in supporting character development and national identity.

Character education is expected to deal with the current challenges that the country is facing. The implementation of education has experienced worrying degradation. Several indicators can be seen to exemplify this condition. The values of local wisdom have been eroded by the negative effect of globalization. The schools have emphasized students' personal intellectual intelligence and take it into consideration to determine education success. In addition, the Indonesian diversity has been threatened by the efforts to force the uniformity in several aspects of life. These conditions have brought an impact on the part of children. They have no space to express creativity in terms of education, culture, arts and etc (Yaumi, 2014). In addition, they have accustomed to play modern games and electronic games which are based on internet networks. These conditions require effort so solve the problem on the parts of Government, parents, society and school. One of the possible options is to apply traditional games which can be an alternative solution in implementing character education among students (Saputra, 2017; Haerani, 2013).

Traditional games are simple in many ways. They are considered as national cultural asset and are used to teach children values and character (Audi, 1999). They are usually made directly by the players. In terms of materials, they require items, objects or plants that are available around the players' environment. When it comes to creativity, they encourage children to be more and more creative in producing the tools. Speaking of rules, they have no written rules. Players usually apply the rules that are commonly used and are adjusted to the agreement among the participants. In other words, the performers are required to be creative in establishing the rules that suit their circumstances. The traditional games should be preserved by the country since they are easy to make and play and also enable children to learn character values in a fun and entertaining way (Mulyani, 2013).

Traditional games are aimed at introducing and preserving the educational values that parents and society try to pass to their children. They have a tremendous influence on children's mental and physical development. According to (Wibisono, 2015) most of the traditional games are played in groups which to some extent provide children opportunities for interaction and communication to occur. This is to say that the games offer strong nuances of togetherness and unity for the children to internalize while they play (Zayyadi et al., 2018). In the same vein, Aypay, (2016) and Palumbo et al., (2019) also reported that traditional 
games helped children to learn subjects like sports and also cultural values in a fun way. Likewise, traditional games improve students' cognitive in their learning activity process (Widiana et al., 2018). The same findings were reported by (Gulia \& Rajesh, 2019) in India concerning their traditional game and their current condition, (Alfarero \& Mejarito, 2014; Morales, 2016) concerning traditional game in Philippine.

Traditional games benefit children and contribute to their proper development. They have attracted scholars to investigate the benefits for education. A number of studies have explained that traditional games can be a medium to teach children social skills, adaptability, interaction ability to prepare them to get along with their peers in the real life. They contribute to children's ability to control themselves, to develop empathy with friends, to obey rules, and to respect others (Rina, 2014). Yudi Winata and Handoyo suggest that children who perform traditional games have much more potential to develop their cooperation skills, sportsmanship, ability to build strategies, agility (running, jumping, balance). In addition, children who perform traditional game develop their character better than children who do not (Yudiwinata \& Handoyo, 2014). Meanwhile, Ekawati et al., (2010) explained that traditional games have an effect on developing children's intrapersonal intelligence. Likewise, (Hidayati, 2020) who deliberately conducted research on traditional games in Indonesia reported similar findings. Saputra (2017) reported that traditional games improve basic ability of children for schooling. Akbari et al., (2009) reported that traditional games influence fundamental motor skill development of children.

Indonesia has a rich cultural diversity and its tribes offers various traditional games to explore. In Bugis tribe, children play traditional games such as massempe 'and mappasajang. In Bone Regency, children usually play traditional games at their school. They have many options to perform the traditional games like in rice fields, yards or fields around their residence. The traditional game can be used as a medium to preserve a particular local wisdom, and social values. They serve as an effort to strengthen character education in society. The efforts to strengthen character education in schools is based on Presidential Regulation No. 87 of 2017. The objectives of strengthening character education are to (1) develop and equip students with the spirit of Pancasila and character education to prepare for their future as the golden generation of Indonesia in 2045, (2) develop a character education platform which serves as the core media in providing education for students with the support of public involvement through formal, non-formal and informal education channels, and (3) revitalize and improve the competence of educators, education staff, students, society and the family environment in implementing character education. Traditional games are assets that are characteristic of a nation's culture, that's why character education can be formed through traditional games from early childhood. (Audi, 1999).

To date, the studies on Bugis traditional games like mappasajang are limited to social studies conducted by Anthropological scholars (Sumilih, 2016). Studies that are aimed to investigate the potential of traditional game mapasajang to teach character values have not been conducted by scholars. This study tries to fill the gap. It was aimed at investigating Bugis' traditional game mappasajang using socio-pedagogical perspective to obtain character values and the contribution that can be offered to strengthen character education for students at Madrasah Ibtidaiyyah Amir Al-Jannah Tipupule, Bone Regency.

\section{METHOD}

This study applied qualitative descriptive. It took place at MI (madrasah ibtidaiyyah/elementary school) Ibtidaiyah Amir al-Jannah Tippulue where the students in the school participated in the mappasajang traditional game. A pedagogical approach and a sociological approach were applied in this study. The data were two types: Primary and 
secondary data. The former refers to data which were obtained directly from the results of observations and interviews with informants (community and educational leaders). The latter included data that was obtained from a number of written works related to traditional games such as books and related scholarly journals. Data collection techniques included observation, interviews and documentation. The data were analyzed using interactive model analysis techniques both during data collection in the field and after the data was collected (Sudarsono, 1992). Triangulation technique was deployed to test the validity of the data used ranging from source, method and time (Sanafiah, 2001).

\section{RESULTS AND DISSCUSSION}

This study found data to achieve the objectives of the study. The findings will be organized and presented in this section. They cover the literature review, the character values offered in mapasajang and the contribution of mapasajang to character education efforts for students at Madarsah Ibtidaiyah Amir al-Jannah Tippulue.

\section{Bugis' Traditional Game: Mappasajang}

Bugis tribe has several traditional games that are preserved and usually performed by the children. (Wibisono, 2015) mentions at least there are 25 types of traditional games that are available and popular to perform by the children. They include (1) maccukke, (2) santo', (3) $m a^{\prime}$ dende, (4) ma'longga, (5) mattojang, (6) mallogo, (7) marraga, (8) makkatto, (9) tingko-tingko, (10) majekeka, (11) ma' boi, (12) mariringgo, (13) massampek, (14) akmemu-memu, (15) abbatu samba, (16) gallakgallak, (17) aklobang, (18) akbombo-bombo, (19) baguli, (20) lambasena, (21) ma' benteng, (22) belkan, (23) mappasajang, (24) magguleceng, and (25) maggasing. One of the most popular games is mapasajang. It is usually played by the people of Tippulue, Toro, Tanete Riattang Timur, Bone Regency. Since many tournaments are frequently held for mapasajang, this traditional game is very familiar to people from all walks of life including students of Madarsah Ibtidaiyah Amir Al-Jannah Tippulue (Kasmawati, personal communication, October 3, 2020).

Mappasajang game is a term used to denote a type of kite that is played together by both male and female. The term "sajang" means "floating". The Bugis who live in Sidenreng Rappang named it "malambaru", derived from the word "lambaru", meaning stingray. The name is used to refer to the form of the main equipment of this game which resembles a stingray. Currently the term "mappasajang" has been rarely used since the more popular term kite games are widely used by the people. There are several things to prepare before players perform mapasajang. Initial preparation requires participants to make mapassajang first. The materials needed consist of: (1) one strong bamboo stick (2) threads (3) piece of paper (4) strong long threads (5) scissors, ruler and (6) glue. Using those materials, players can follow certain procedures to make a kite or mappasajang. Historically speaking, the people for the first time made their kites using material from wide and dry leaves and ropes. As the the use of paper was introduced, Bugis people began to use paper as the main material for making kites (Roswati, personal communication, October 5, 2020).

The are several procedures and techniques of making mapassajang (kite) (Agustan, personal communication, November 24, 2020). Explains the procedures as follows: first, the bamboo is cut according to the desired size for two pieces. Second, the two bamboo pieces are linked in a cross-like manner using threads so that there are four ends of the bamboo pieces. Third, the four ends of the bamboo are connected using threads. Fourth, when the frame is complete, it is then placed on the paper and the paper is cut according to the pattern. Fifth, the paper is glued on the pattern thread. Finally, a long thread as a rope is tied at the point where the two previous bamboos meet, forming a simple mapassajang. The shapes and decorations for the mapassajang (kite) that are made vary depending on the taste of the maker. 
Technically speaking, the shape and decoration of the kites played in the festival vary. However, Bugis people generally use animal shapes and patterns to design their kites.

There are some points to consider to make mapasajang interesting and entertaining to play. First, the teams made their kites with various models and styles. Then, they made pitupitu, a special tool that is attached to the back of the kite. Pitu-pitu is geared toward producing a beautiful sound and rhythm during the game is performed. Next, the teams prepared to fly the kite. To be successful at this stage, they need a good steady wind to let the kite fly away (Agustan, personal communication, November 24, 2020; Roswati, personal communication, October 5, 2020). This game of "sajang" or kite requires players" skill and strength. This traditional game is considered a pride of traditional society. It is at the same time exciting to perform.

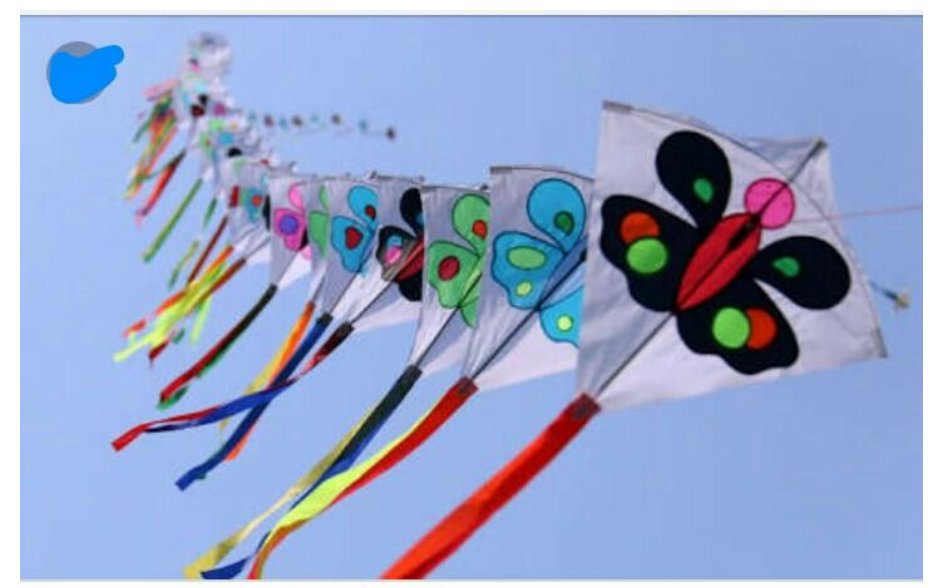

Figure 1. The Kite Mapasajang that has been Made and Flied (source:kabarsinjai.com)

Mapasajang players hold their kite up by the bridle point and they let the line out. They need a sufficient wind so their kite can go right up. The players may let the kite fly away from them a little, then they pull in on the line as their kites point up so they will climb. They can repeat this until their kites gain the altitude necessary to find a good steady wind. If their mapasajang has been successfully flown with a dynamic nuance, the players receive support from other partners, especially girls around the tournament site. They shouted chants to build enthusiasm for the spirit of the mappasajang players. When two kites collide, they even screamed hysterically. The situation becomes more interesting when their team's kite almost collided with another player's kite. If one kite cuts off the string of its opponent, it emerges winner. This condition creates a funny and happy atmosphere (Agustan, personal communication, November 24, 2020; Roswati, personal communication, October 5, 2020).

Traditional games for children are a form of folklore since they are preserved and carried out orally in a traditional form. They have been passed down from generation to generation. They sometimes have no exact origin, creator and area of origin because they are recorded in the form of oral. Sometimes they undergo changes in names or forms even though they are based on the same. For example, congklak in West Java and the dakon in Central Java have one thing in common since they apply the same rules and ways of playing. They are called differently with respect to its place. The traditional games are inherited and are performed for fun (Dananjaya, 1987).

Flying kite is considered a universal phenomenon since it exist in almost every culture in the world. Regardless of the country and the geographical borders, children enjoy flying kite and it has been nurtured by their parents and society. This is in line with the studies conducted by researcher like Gulia \& Rajesh (2019) who reported traditional game flying kite in India. 
Other researcher also reported similar finding in Philipine (Alfarero \& Mejarito, 2014; Morales, 2016).

\section{Character Values that Can Be Obtained from Bugis' Traditional Games}

Traditional games try to teach important values for children in their life. The values are important to be passed on to future generations so that they are able to develop strong characters. The future generations are expected to be able to survive amidst challenges in their life. To be successful in life, children should be taught not only science and technology but also skills and character. Bugis' traditional game mappasajang have character values that can support the dignity of social life.

Based on the results of interviews with a number of figures, this study found that there are some character values that can be obtained from mappasajang traditional game. First, sabbara (patience). The players learn this character when they practice flying a kite which require patience. Sometimes it takes longer time to fly the kite if the wind is not sufficient. Second, macaradde (creativity). The players earn this character when they make kites with attractive models, patterns and decorations. In addition, they apply pitu-pitu (sound instrument) accessories that make a beautiful sound for their kites. Third, asseddi seddingeng (unity). mappasajang game is performed in group, at least a partner is needed. This traditional game can cultivate cohesiveness and unity. Fourth, warani (brave). In mappasajang, the players try their best to create beautiful rhythms to perform best. It requires courage and strong conviction to create rhythm. Fifth, courage in massempe 'games appears in the players' efforts to become great players. Fifth, tawakkal or submission to Allah (mappesona ri dewata seumwae). Players try to perform tawakkal when they play mapasajang by managing all their effort to perform best and submit themselves to Allah for the result. When the participants play, they try to perform optimally and they do not take the audience existence as a burden. Sixth, sumange teya lara' (the spirit of never giving up). The players should strive to perform best mapasajang in the midst of burdens and other challenges. They should survive and try their best to fight against all odds in playing the kite. Seventh, honesty and sportmanship (melempu). The traditional mappasajang game teaches players honest character and sportsmanship during their performance. They mustn't cheat other players to win the competition. Eighth, grateful attitude (sukkuru). The players perform mappasajang as parts of their grateful attitude to God on the gift they receive in terms of harvest they gain every year. The faces of joy that appeared on the faces of the players and spectators conveyed gratitude to God (Caco, personal communication, November $24,2020)$.

Through traditional games, character values can be passed on to the younger generations of the Bugis community. It is part of inheritance of local wisdom. Students from MI are introduced to the meaning, history and philosophy of life of their Bugis ancestors who live modest, respect each other, uphold togetherness, and help each other. Strengthening character values through Bugis' traditional games has an impact on all aspects of the educational environment, both family, school and community. In the family environment, parents receive assistance to teach character education through Bugis traditional games. This can be seen, among other things, from the values of working together before and after the event. In the family scope, efforts to make kites generally involve parents and children together. There is a chance to foster a sense of love, mutual affection between father and child. At the same time the mothers provided small meals and snacks (Syahriana, personal communication, November 20, 2020).

Bugis traditional game like mapasajang has an impact of strengthening character education. It can foster children's character values such as the character asseddi-seddingeng (unity and togetherness) by inviting them to work together. There were many activities where children took a part in a particular large event such as: entertaining guests with traditional 
food, such as onde-onde, bandang-bandang, barongko, katiri sallang (Agustan, personal communication, November 24, 2020; Ake, personal communication, November 20, 2020). emphasizes that the traditional Bugis games displayed by students are indirectly a form of embodiment of character values that are useful for their cognitive, attitudes and psychomotor development. The character values developed in traditional games are in line with the implementation of the 2013 curriculum which focuses on strengthening character education for participants.

The impact of strengthening character education through traditional Bugis games for students can be seen in the context of forming a community that upholds the values of local wisdom such as mutual respect, mutual assistance, and unity to create common ideals. (A. P. Pawi, personal communication, November 24, 2019) A united society can form a peaceful, tolerant society, so that it can protect and deal with the challenges and in social life. (Hukmiwati, personal communication, October 4, 2020) emphasizes that Bugis traditional game is a form of cultural preservation. The local government facilitates the implementation of traditional game events until they are successfully held.

Regarding the noble value of a tradition, it is necessary for humans to understand the social changes, so that the traditional values to be preserved can be translated in every behavior. Without proper understanding on the traditional values, a person or society is in a difficult position to determine success or failure when they deal with challenges in life. Every human being should try to fulfill the guidance set in a proper traditional value when it comes to deal with his or her life. The efforts made in developing the noble values of a tradition can be done by developing: (1) moral values based on religious values, (2) mutual respect and respect among each other, (3) a way of life of mutual help in togetherness, (4) social care and caring attitude among fellow communities, and (5) the values in a tradition (Andriani, 2012; Aneka \& Rahmatika, 2019; Rina, 2014).

When it comes to child development, studies have shown that the traditional game mappasajang has a positive contribution. It benefit children both physically and mentally because it can develop their intellectual intelligence. According to (Rusydi, 2019), the kite is a powerful medium to instill independence value in children, as well as an effective learning medium. This means that children should be taught to dare to challenges of life so they can strive to achieve success. In the game, the kite must be held by the rope which provides lesson that there is a need for parental control in educating children. In the context of children, the game is also in line with the principle that learning while playing is better than learning in a serious manner. In line with this, Kurniati (2016) reported that traditional games can develop the potential of each child. It can be seen from social adjustment behavior of the children when performing the game. They also learn to preserve and love the nation's culture. In West Java, the traditional games have entertainment-based prestigious skills and they can be found everywhere. It is interesting to note that the traditional games of West Java contain elements of physical education (gymnastic), accuracy, agility, thinking power, appreciation of the existing art elements, and refreshment for the mind. Likewise, the research conducted by (Lubis \& Khadijah, 2018) reported that traditional games have benefitted child development and it is one of the positive effects of traditional games.

Mapasajang is a traditional game featuring kite as primary feature to perform. This game has the potential to teach character values for the students. (Susanto, 2007) empirically shows that kite games are popular with all groups, from children, adolescents to adults. The game, even though the actors are dominated by men, is full of values such as cooperation value, skill value, creativity value, competitive value, and aesthetic value. 


\section{Contribution of Bugis' Traditional Games for Strengthening Character Education}

Traditional games contribute to strengthening character education and dimensions of social life. The positive contributions of these traditional Bugis games can be described in the following areas.

\section{Education}

Bugis traditional games can form positive character education values for students at school and at home. Students are instilled in having a cooperative attitude with friends at school and educators so that they can help each other and be respectful to their educators. This cooperative attitude can develop the sympathetic and empathic attitudes of students towards friends and educators. The behaviors can be translated in the form of visiting friends who are sick, giving gifts to friends in need, praying for everyone and etc. Attaining the character values from Bugis traditional games, students are always enthusiastic in learning for their future life provisions.

At home, students can study diligently, help their parents work at home or work around their neighborhood. Bugis traditional games has the strength to develop the mentality of students towards a stable personality, uphold the values of togetherness, promote hard work, and teach not to give up against all odds. In summary, the traditional game has the potential to instill characters that children need later when they grow up (Suriati, personal communication, December 3, 2019).

2. Social

Bugis traditional games teach the importance of social roles between men and women. This can be seen in the mappasajang game when the men are tasked with making and flying the kites. On the other hand, the women prepare the raw materials for the kites and they support players as cheerful figures when players manage their effort to fly the kite in the air. If a string breaks and the kite drops back to the ground, the children run after the kite (pasajang) even though it is not their kite. They were happy when they managed to find a fallen kite. This game has instilled an attitude of social care that has been deeply embedded in people's lives. In addition to social care, the traditional games also have promoted gender equality. Even though the mappasajang game is dominated by men, women play their roles by shouting chants and admiring the kites that can fly high with beautiful models, colors, characters, and sounds. Women have involved in the game and their participation makes this game interesting. (Nurfadilah, personal communication, December 4, 2019)

At school, students uphold these traditional values so that they always make true friendships and do not discriminate or make fun of each other due to different genders. They can look after each other and work together to improve the school and its hometowns. This is the source to nurture social skill (Nugraha et al., 2018). This value is an asset in the future they will live in a society with a variety of problems and dynamics. If they are not strong enough to hold a positive tradition, the individual in society will lose their function and prestige in the community.

\section{Economy}

Bugis traditional games promote hard work for people to strive economically. In developing the community's economy, the traditional games have enabled the people who are involved in traditional games to indirectly benefit financially as an economic source through trading activities in various foods, drinks and clothing. Traditional game performances have opened up a local economic field that helps the needs of the community in doing business. (Kamiruddin, personal communication, October 4, 2019).

On the part of students, traditional game performances have taught them lesson on how to live independently. They should not depend themselves to other parties so that they can harness their independence character. A person who is able to live independently will survive 
anywhere. This is evident from the fact that the Bugis in general became immigrants and were successful in overseas.

\section{Health}

Bugis traditional games require high body work because they require movements which are fast and precise. Bugis people believe that body movements can cause a person to become healthy. According to Kamiruddin, for Bugis people, sport is necessary because they understand the expressions " ripakedo-kedona lappa-lappa lanro alewe sarekkoammengngi namaseddi larinna darae nassabari namakessing lanro alewe namajjappa watakkalewe moloi jama-jamang" " (when the body is moved, all the muscles of the body move and pump the blood to achieve proper circulation. The body becomes healthy and it causes enthusiasm to work) (Kamiruddin, personal communication, October 4, 2019). The Bugis traditional game evokes the spirit of diligently exercising to support physical health. Physical health can support performance at work and other activities. Students who are involved in traditional Bugis games are indirectly taught to live a healthy life by exercising. Healthy living can provide encouragement, as well as capital for activities in studying and working at home.

The traditional game mappasajang which teaches character values can be a medium for strengthening character education, especially among students of madrasah ibtidaiyyah. This is in line with the government program which is stated in the Presidential Regulation No. 87 of 2017. This regulation serves as the legal basis for strengthening character education in schools. This confirms that strengthening character education for students is not only the task of the teacher at school, but the responsibility of all elements, including parents and community leaders (formal, informal and non-formal). This is relevant to (Wulansari, 2017) research at PAUD (Pendidikan Anak Usia Dini/Early Childhood Education School) which shows that PAUD is a meeting place for children to socialize. PAUD is the right place to introduce traditional games in various activities in the curriculum. PAUD institutions are given the freedom to develop their curriculum.

The significance of traditional games as a medium for strengthening character education is also based on the impact of modern games which penetrate school-age children. Traditional games were very popular before modern technology occupied Indonesia. Elementary school age children played using traditional tools. Now, they are playing with modern technologybased games from abroad and are starting to leave traditional games. Traditional games are slowly disappearing so that children do not know traditional games. The character value of the child is getting lost due to the arrival of imported games (Booc et al., 2019; Saputra, 2017; Sumilih, 2016) emphasizes that traditional games that have spread among the people of the archipelago, including the Bugis-Makassar community, need to be explored for their potential in building students' character.

There are many things to consider for the safety of children in playing mapasajang. Parents needs to warn their children to pay attention to the situation and conditions, because they usually play the kites in the middle of the day. They should also advise their children not to play kite excessively to avoid being sick due to fever. In addition, children play mappasajang in residential areas and hunt the kites in the road risking their safety. They also climb the trees to get their kites, and even climb the roof of the house to get their kites (Agustan, personal communication, November 24, 2020; Hukmiwati, personal communication, October 4, 2020).

\section{CONCLUSION}

The Bugis traditional game mappasajang performed by students of Madrasah Ibtidaiyah Amir al-Jannah Tippulue has offered character values to internalize for their development. These character values include: patience (sabbara), creativity (macaradde), unity (asseddi seddingeng) and cooperation (reso temmangingi), courage (warani), tawakeal (mapp Pesona ri dewata seuwwae), never 
giving up (teya lara'), honest (melempu), and being grateful (sukkuru) (gratitude). The character values in the traditional game of mappasajang contribute to strengthening character education in all aspects of Bugis community life, be it education, economy, and health. In the field of education, these character values can develop student's stable personality, uphold the values of togetherness, nurture the attitude of hard work, and train attitude of never giving up and other characters needed later when they grow up. In the social field, traditional games are full of equality values, thus fostering gender equality. In the economic field, traditional games are able to move the economy of rural communities. This can be seen from the participation of traders in selling their merchandise. These traditional games are a cultural promotion ground for the government. In the field of health, the traditional Bugis games motivate people to become hard workers. Efforts to support hard work require a strong and healthy body.

\section{BIBLIOGRAPHY}

Akbari, H., Abdoli, B., Shafizadeh, M., \& Khalaji, H. (2009). The Effect of Traditional Games in Fundamental Motor Skill Development in 7-9 Year-Old Boys. Iranian Journal Pediatrics, 19(2).

Alfarero, J. A., \& Mejarito, C. L. (2014). Traditional Games in Leyte and the Values Learned by the Players. University of the Visayas -Journal of Research, 8(1), 269-280. https://doi.org/10.5281/zenodo.2139926

Andriani, T. (2012). Permainan Tradisional dalam Membentuk Karakter Anak Usia Dini. Jurnal Sosial Budaya, 9(1). https://doi.org/10.24014/sb.v9i1.376

Aneka, \& Rahmatika, A. (2019). The Benefits of Traditional Game "Clogs" to Develop Early Childhood's Rough Motoric. Elementary Jurnal Ilmiah Pendidikan Dasar, 5(1), 107. https://doi.org/10.32332/elementary.v5i1.1498

Audi, R. (1999). The Cambridge Dictionary of Philoshofby (Second). Cambridge University Press.

Aunillah, N. I. (2011). Pendidikan Karakter di Sekolah. Jakarta: Laksana.

Aypay, A. (2016). Investigating The Role of Traditional Children's Games in Teaching Ten Universal Values in Turkey. Eurasian Journal of Educational Research, 62, 283-300. https://doi.org/10.14689/ejer.2016.62.14

Azra, A. (2002). Konflik Baru antar Peradaban: Globalisasi, Radikalisme \& Pluralitas. Divisi Buku Perguruan Tinggi, RajaGrafindo Perkasa.

Booc, R. P., Rafaela, K. B., Torres, M. J., Bulawan, R. P., Jabonero, L. C. II, Cortuna, I. J. M., \& Asuncion, J. E. (2019). The Traditional Filipino Games: Status Check Among Generation Z. Theoretical \& Applied Science, 78(10), 150-152. https://doi.org/10.15863 /TAS.2019.10.78.25

Dananjaya, J. (1987). Folklor Indonesia. Jakarta: Pustaka Grafiti.

Direktorat Jenderal Pendidikan Islam. (2016). Modul Pelatiban Anggaran Responsif Gender (ARG) dan Perencanaan dan Penganggaran Responsif Gender (PPRG) Bidang Pendidikan Islam. Jakarta: Kementerian Agama RI

Ekawati, Y. N., Saputra, N. E., Rozalina, Restya, W. P. D., \& Nurlita, I. (2010). Pengaruh Bermain melalui Permainan Tradisional terhadap Kecerdasan Intrapersonal Anak. Jurnal Ilmiah Mahasiswa Berprestasi, 1(2).

Gulia, S., \& Rajesh, D. (2019). Traditional Games in India: Their Origin and Status in Progressive Era. International Journal of Physiology, Nutrition and Physical Education, 4(1), 1252-1254.

Haerani, N. (2013). Membangun Karakter Anak melalui Permainan Anak Tradisional, Jurnal Pendidikan Karakter, 3(1). https://doi.org/10.21831/jpk.v0i1.1290 
Hidayati, N. N. (2020). Indonesian Traditional Games: A Way to Implant Character Education on Children and Preserve Indonesian Local Wisdom. ISTAWA: Jurnal Pendidikan Islam, 5(1), 81-101. https://doi.org/10.24269/ijpi.v5i1.2475

Kurniati, E. (2016). Permainan Tradisional dan Perannya dalam Mengembangkan Keterampilan Sosial Anak. Jakarta: Kencana.

Lubis, R. \& Khadijah. (2018). Permainan Tradisional sebagai Pengembangan Kecerdasan Emosi Anak. Al Athfal Jurnal Pendidikan Anak, 4(2).

Morales, M. P. E. (2016). Exploring Indigenous Game-based Physics Activities in Pre-Service Physics Teachers' Conceptual Change and Transformation of Epistemic Beliefs. Eurasia Journal of Mathematics, Science and Technology Education, 13(5), 1377-1409. https://doi.org/10.12973/eurasia.2017.00676a

Mulyani, S. (2013). Sri Permainan Tradisional Anak Indonesia. Yogyakarta: Langen Sari Publishing.

Mulyasa, E. (2011). Manajemen Pendidikan Karakter (I). Jakarta: Bumi Aksara.

Nugraha, Y. A., Handoyo, E., \& Sulistyorini, S. (2018). Traditional Game on The Social Skill of Students in The Social Science Learning of Elementary School. JPE: Journal of Primary Education, 7(2). https://doi.org/10.15294/jpe.v7i2.23475

Palumbo, C., Ambretti, A., \& Kourkoutas, E. (2019). Traditional Games Body and Movement. Journal of Sports Science 7, 33-37. https://doi.org/10.17265/2332-7839/2019.01.005

Rina, W. (2014). Permainan Tradisional sebagai Media Pengembangan Kemampuan Sosial Anak. Cakrawala Dini Jurnal Pendidikan Anak Usia Dini, 5(1). https://doi.org/10.17509/cd.v5i1.10496

Rusydi, M. (2019). Implementasi Nilai-nilai Pendidikan Karakter dalam Permainan Tradisional Bugis di Kabupaten Bone in Forum Grup Discussion 19 Agustus 2019, Bone.

Sanafiah, F. (2001). Metodologi Penelitian Sosial (I). Erlangga.

Saputra, S. Y. (2017). Permainan Tradisional VS Permainan Modern dalam Penanaman Nilai Karakter di Sekolah. ELSE: Elementary School Education Journal, 1(1). https://doi.org/10.30651/else.v1i1.873

Sudarsono. (1992). Beberapa Pendekatan dalam Penelitian Kualitatif. Yogyakarta: Gajah Mada University Press.

Suhra, S. (2016). Strategi Guru Pendidikan Agama Islam dalam Implementasi Pendidikan Karakter (I). Gunadarma Ilmu.

Sumilih, D. A. (2016). Pembangunan Karakter Peserta Didik: Pengkondisian RAS melalui Pemanfaatan Potensi Permainan Tradisional Bugis-Makassar. Seminar Nasional "Pendidikan Ilmu-Ilmu Sosial Membentuk Karakter Bangsa dalam Rangka Daya Saing Global" 17-26.

Susanto, E. (2007). Kemungkinan Munculnya Paham Islam Radikal Di "Pondok Pesantren." TADRIS: Jurnal Pendidikan Islam, 2(1). https://doi.org/10.19105/tjpi.v2i1.205

Wibisono, D. P. (2015). Mengenal Permainan Tradisional Sulawesi Selatan Warisan Nilai-nilai-Lubur yang tak Lekang oleh Waktu (I). Makasar: Arus Timur.

Widiana, I. W., Jampel, I. N., \& Prawini, I. P. (2018). The Effectiveness of Traditional GameBased Communication Learning Activity for Cognitive Process Dimension Learning Achievement. Cakrawala Pendidikan, XXXVII (2), 260-269. https://doi.org /10.21831/cp.v37i2.14091

Wulansari, B. E. (2017). Pelestarian Seni Budaya dan Permainan Tradisional melalui Tema Kearifan Lokal dalam Kurikulum Pendidikan Anaka Usia Dini”. Jurnal Indria Jurnal Ilmiah Pendidikan Pra Sekolah dan Sekolah., 2(1), 1-11. https://doi.org/10.24269 /jin.v2n1.2017.pp1-11 
Yaumi, M. (2014). Pendidikan Karakter Landasan, Pilar dan Implementasi (I). Kharisma Putra Utama.

Yudiwinata, H. P., \& Handoyo, P. (2014). Permainan Tradisional dalam Budaya dan Perkembangan Anak. Jurnal Paradigma, 2(3). Retrieved from https://jurnalmahasiswa.unesa.ac.id/index.php/paradigma/article/view/9088

Zayyadi, M., Hasanah, S. I., \& Surahmi, E. (2018). Ethnomatematics Exploration in Traditional Games as A Form of Students' Social Interaction. JIPM: Jurnal Ilmiah Pendidikan Matematika, 6(2), 125-132. http://doi.org/10.25273/jipm.v6i2.1826 